\title{
ANALISIS KORELASI SIKAP ILMIAH DAN HASIL BELAJAR KOGNITIF SISWA MELALUI MODEL PBL
}

\author{
Aminah Tri Putri ${ }^{1 *}$, Irdam Idrus ${ }^{1}$, Yennita $^{1}$ \\ ${ }^{1}$ Program Studi Pendidikan Biologi, Fakultas Keguruan dan Ilmu Pendidikan, Universitas Bengkulu \\ email : aminahtriputri@gmail.com
}

\begin{abstract}
ABSTRAK
Penelitian ini bertujuan untuk mengetahui ada tidaknya korelasi sikap ilmiah dan hasil belajar kognitif siswa. Metode yang digunakan dalam penelitian ini adalah metode korelasional dengan subyek penelitian adalah siswa pada kelas $\mathrm{VII}_{2} \mathrm{SMP} N 4$ Bengkulu yang berjumlah 33 orang. Sikap diukur menggunakan angket sikap ilmiah dan hasil belajar kognitif siswa diukur menggunakan tes tertulis dengan model PBL (problem based learning) pada materi saling ketergantungan antar komponen biotik. Data dianalisis dengan rata-rata, standar deviasi, dan persentasenya serta korelasinya diuji menggunakan program SPSS versi 22.0. Berdasarkan perhitungan didapatkan rata-rata skor sikap ilmiah siswa sebesar 48,5 dengan standar deviasi yaitu 0,25 dan termasuk kategori sikap ilmiah sangat baik. Rata-rata skor hasil belajar kognitif siswa adalah 3,16 dengan standar deviasi 0,262 dan termasuk kategori hasil belajar kognitif sangat baik. Jika dibandingkan dengan $\alpha=0,05$, nilai signifikansi lebih kecil daripada nilai $\alpha$, yaitu $0,005 \leq 0,05$. Artinya, ada korelasi yang signifikan antara sikap ilmiah dan hasil belajar kognitif dan HO ditolak. Sehingga disimpulkan bahwa sikap ilmiah berkorelasi dengan hasil belajar kognitif siswa kelas $\mathrm{VII}_{2} \mathrm{SMP} \mathrm{N} 4$ Bengkulu pada pembelajaran IPA Biologi dengan model Problem Based Learning, dan angka indeks korelasi yaitu 0,482 yang menunjukkan korelasi searah dengan tingkat hubungan tergolong sedang.
\end{abstract}

Kata kunci: hasil belajar kognitif, model PBL (Problem Based Learning), sikap ilmiah

\begin{abstract}
The aimed of this research was to know whether or not there was correlation between the students's scientific attitude and the result of student's cognitive. The method used in this research was correlational method with subject of research is student in class VII2 SMP N 4 Bengkulu which amount to 33 people. Attitude was measure used a questionnaire of scientific attitudes and the result of student's cognitive were measure used a written test after learning with a PBL (problem based learning) model on the interdependent material between biotic components. Data were analyzed by mean, standard deviation, and the percentage and correlation were tested using SPSS version 22.0. Based on the calculation, The result of the research got the mean student's scientific attitude was 48.5 , with standard deviation of 0.25 and belongs to the category of excellent scientific attitude. The mean of the result of student's cognitive was 3.16 with a standard deviation of 0.262 and includes a very good category. When compared with $\alpha=0.05$, the value of significance was smaller than the value of $\alpha$, which was $0.005 \leq 0.05$. There was significant correlation between scientific attitude and the result of student's cognitive, and meanwhile HO rejected. So it is concluded that the scientific attitude correlated with the the result of student's cognitive at VII2 SMP N 4 Bengkulu on science learning Biology by using Problem Based Learning model, and the correlation index number was 0.482 which showed the correlation in the one way that had classified middle level.
\end{abstract}

Keywords: the result of student's cognitive, PBL model (Problem based learning), scientific attitude

\section{PENDAHULUAN}

Pendidikan IPA diharapkan dapat menjadi wadah bagi siswa untuk mempelajari diri sendiri dan alam sekitar, serta penerapannya dalam kehidupan sehari-hari. Berdasarkan harapan tersebut, permendikbud Nomor 58 tahun 2014 menjelaskan bahwa pelajaran IPA di SMP/MTs bertujuan agar peserta didik memiliki beberapa kompetensi diantaranya yaitu agar peserta didik dapat menunjukkan perilaku ilmiahnya, mampu mengembangkan kemampuan berpikirnya, mampu memecahkan permasalahan yang diberikan serta mampu menguasai konsep dan prinsip IPA. Sejalan dengan peraturan tersebut, tujuan mata pelajaran tersebut salah satunya mengharapkan agar peserta didik 
memiliki kemampuan dalam mengembangkan rasa ingin tahu, objektif, jujur, tekun, hati-hati, bertanggung jawab, terbuka, kritis dan peduli akan lingkungan sekitar. Berdasarkan landasan hukum tersebut, disebutkan bahwa sikap yang dimiliki peserta didik dapat dijadikan salah satu tolak ukur keberhasilan suatu pembelajaran yang dilakukan. Sikap ilmiah khususnya dalam pembelajaran IPA merupakan salah satu aspek penting yang harus dimiliki oleh siswa dan tidak boleh diabaikan oleh guru dalam melakukan penilaian. Menurut Kartono (2012), sikap ilmiah memiliki peran yang penting dalam menemukan konsep suatu pembelajaran serta siswa dapat membangun gagasan baru sewaktu mereka berinteraksi dengan suatu gejala.

Pada kondisi di kelas $\mathrm{VII}_{2}$ tersebut, terdapat beberapa permasalahan yang perlu mendapatkan perhatian khusus, yaitu: 1) sikap ingin tahu siswa rendah, tercermin dari rendahnya jumlah siswa yang bertanya. 2) siswa tidak terbiasa untuk melakukan kerjasama, karena guru memberikan materi hanya dengan cara menjelaskan. 3) siswa mudah sekali mengeluh dan berkata "tidak bisa" terhadap kegiatan pembelajaran yang tidak biasa dilakukan oleh siswa. 4) kebanyakan siswa hanya mengerjakan asal tugas yang diberikan oleh guru, sehingga tugas yang dibuat oleh siswa tidak selalu memuaskan. Dari permasalahan yang timbul tersebut, yaitu karena guru tidak terbiasa menyajikan pembelajaran dengan kegiatan berbasis metode ilmiah, guru hanya terfokus pada materi yang diajarkan, siswa tidak pernah dibiasakan untuk memperhatikan sikap saat proses pembelajaran, sehingga hasil belajar yang menjadi orientasi siswa adalah hasil belajar pada ranah kognitif saja.

Selain itu, guru di sekolah juga mengharapkan $\quad 75 \% \quad$ siswanya mendapatkan hasil belajar kognitif memenuhi kriteria ketuntasan minimal IPA Biologi yaitu 75. Rendahnya hasil belajar ini, disebabkan juga karena siswa kurang terlibat aktif dalam proses pembelajaran. Siswa lebih senang mendengar dan menerima apa yang disampaikan tanpa ingin terlibat dalam penemuan konsep tentang materi yang dipelajari. Dalam mempelajari IPA, keterlibatan siswa sangat dibutuhkan agar tercipta suatu pembelajaran yang bermakna melalui aktivitas-aktivitas ilmiah yang dilakukan oleh siswa sehingga perlahan akan membangun sikap-sikap ilmiah dalam diri siswa.

Kurangnya keterlibatan peserta didik dalam proses pembelajaran menyebabkan pembelajaran cenderung berpusat pada guru. Padahal, untuk menumbuhkan pemahaman materi pada siswa akan lebih baik jika siswa lah yang berperan aktif selama proses pembelajaran. Keterlibatan siswa secara aktif dalam pembelajaran akan meningkatkan penguasaan kompetensi pemahaman konsep serta kompetensi kerja ilmiah siswa. Hal tersebut akan tampak pada peningkatan kemampuan berpikir, bekerja dan bersikap ilmiah siswa.

Untuk mengembangkan dan meningkatkan kemampuan siswa dalam memecahkan permasalahan dan bersikap ilmiah dalam pembelajaran IPA, maka diperlukan suatu upaya yang tepat. Salah satunya adalah dengan menerapkan model pembelajaran yang dapat mengembangkan sikap ilmiah siswa, sehingga akan berdampak pula pada peningkatan hasil belajar siswa. Model pembelajaran tersebut adalah PBL (Problem Based Learning). Melalui PBL, konsep IPA Biologi dipelajari oleh siswa dengan pemberian masalah yang berhubungan dengan dunia nyata siswa. Dengan menggunakan model PBL siswa belajar tentang cara bersikap ilmiah, keterampilan memecahkan masalah, serta 
untuk memperoleh pengetahuan konsep yang penting dari materi pelajaran.

Selain itu, pada hakikatnya program pembelajaran tidak hanya bertujuan untuk memahami dan menguasai apa dan bagaimana sesuatu terjadi, tetapi juga memberi pemahaman dan penguasaan tentang mengapa hal itu terjadi. Pemahaman yang hanya mengarah pada apa dan bagaiaman sesuatu terjadi tidak menciptakan daya kritis bagi siswa dalam memecakan suatu masalah (Sutirman, 2013).

Sampai saat ini banyak siswa yang memperoleh nilai tinggi bahkan sempurna, tetapi ketika dalam kehidupan nyata atau di dalam proses pembelajaran menghadapi suatu masalah mereka tidak tahu bagaiamana cara mengatasinya. Hal ini menunjukkan bahwa sikap siswa tidak berbanding lurus dengan hasil belajarnya. Sikap yang dimaksud seperti berpikir kritis, rasa ingin tahu, jujur dan peduli terhadap lingkungan.

Masalah adalah kekuatan utama dalam penerapan pembelajaran berbasis masalah. Masalah dapat merangsang rasa ingin tahu siswa, keinginan untuk mengamati, motivasi, serta keterlibatan seseorang atas satu hal. Putra (2013) menjelaskan bahwa model pembelajaran PBL menekankan keaktifan siswa dan mengunakan masalah kehidupan nyata sebagai sesuatu yang harus dipelajari oleh siswa untuk melatih dan meningkatkan keterampilan berpikir kritis sekaligus pemecahan masalah, serta mendapatkan pengetahuan konsep-konsep penting. Dalam model PBL tidak hanya sekedar menekankan bagaimana siswa mudah dalam belajar, tetapi lebih jauh dari itu yaitu menekankan bagaimana siswa memahami suatu persoalan nyata, tahu solusi yang tepat, serta dapat menerapkan solusi tersebut untuk memecahkan masalah (Sutirman, 2013).
Penerapan model problem based learning dilakukan pada materi interaksi makhluk hidup dengan lingkungannya pada sub materi saling ketergantungan antar komponen biotik. Materi ini memuat tentang keterkaitan antara makhluk hidup yang di hubungkan dengan beberapa pola salah satunya terkait rantai makanan. Hal ini akan menarik perhatian bagi siswa karena masalah yang diberikan akan dikaitkan dengan kehidupan sehari-hari mereka dan diharapkan siswa akan mampu memahami proses interaksi tersebut secara berurutan.

Hasil belajar kognitif dan sikap ilmiah merupakan faktor penting di dalam proses pembelajaran. Tingginya sikap ilmiah yang dimiliki seorang siswa menimbulkan intensitas kegiatan yang lebih tinggi pula. Sehingga kegiatan belajarnya menjadi lebih aktif dan akan memperoleh hasil belajar yang lebih baik dibandingkan dengan sikap belajar yang negatif. Dengan semakin meningkatnya kemampuan kognitif siswa yang ditandai dengan meningkatnya hasil belajar maka akan membentuk sikap ilmiah yang lebih baik dalam diri siswa. Seiring dengan bertambahnya kemampuan kognitif siswa akan memberikan pemahaman bagi siswa mengenai pentingnya memiliki sikap ilmiah yang baik, sehingga siswa membiasakan diri untuk bersikap secara ilmiah terutama dalam proses pembelajaran. Siswa yang berprestasi rendah pada umumnya tidak memberi perhatian yang besar terhadap pembelajaran, sehingga mereka tidak merasa perlu untuk membiasakan dirinya berpikir kritis, ingin tahu, tekun, maupun bekerjasama dengan orang lain (Astuti, 2014).

Tujuan penelitian ini adalah mengetahui sikap ilmiah dan hasil belajar kognitif siswa serta menganalisis korelasi antara sikap ilmiah dan hasil belajar kognitif siswa kelas $\mathrm{VII}_{2}$ SMPN 4 kota Bengkulu pada pembelajaran IPA Biologi 
dengan model PBL (Problem Based Learning).

\section{METODE}

$\begin{array}{lll}\begin{array}{c}\text { Jenis } \\ \text { penelitian }\end{array} & \begin{array}{l}\text { penelitian ini adalah } \\ \text { korelasional }\end{array}\end{array}$
menggunakan metode korelasi. Metode korelasi digunakan untuk memperoleh informasi mengenai korelasi antara 2 variabel yaitu sikap ilmiah meliputi sikap rasa ingin tahu, terbuka, berpikir kritis, tekun serta peduli lingkungan dan variabel hasil belajar kognitif dalam bentuk pemahaman konsep pada pembelajaran IPA biologi dengan materi interaksi makhluk hidup dengan lingkungannya, sub materi saling ketergantungan antar komponen biotik pada KD mendeskripsikan interaksi antar makhluk hidup dan lingkungannya. Subjek penelitian ini adalah seluruh siswa kelas $\mathrm{VII}_{2}$ SMP N 4 kota Bengkulu sebanyak 33 siswa yang terdiri atas 11 siswa dan 22 siswi.

Data yang akan dikumpulkan meliputi data sikap ilmiah dan hasil belajar kognitif siswa serta hasil dari analisis korelasi antara sikap ilmiah dan hasil belajar kognitif. Teknik yang digunakan untuk mengumpulkan data sikap ilmiah yaitu angket, sedangkan untuk mengetahui hasil belajar kognitif digunakan teknik tes tertulis atau post-test. Instrumen penelitian terdiri atas lembar angket sikap ilmiah dan lembar tes hasil belajar kognitif siswa.

Pada lembar angket, butir angket yang digunakan yaitu angket tertutup atau terstruktur dan alternatif jawaban disediakan sesuai dengan skala likert. Untuk memudahkan penggolongan dan statistiknya, maka dari setiap item soal diberi skala dengan 4 tingkatan yaitu sangat setuju (SS), setuju (S), tidak setuju (TS), dan (STS). Untuk pernyataan positif skala 1 berarti sangat negatif dan skala 4 berarti sangat postif, begitu sebaliknya (Widyoko, 2012).

Lembar tes hasil belajar kognitif dikembangkan dengan menganalisis indikator yang telah ditetapkan berdasarkan kompetensi inti dan kompetensi dasar pada kurikulum 2013 serta buku IPA Biologi SMP/MTs kelas VII. Indikator tersebut adalah mendeksripsikan bentuk saling ketergantungan di antara komponen biotik dan menjelaskan salah satu proses bentuk saling ketergantungan di antara komponen biotik.

Data sikap ilmiah dan hasil belajar kognitif siswa dianalisis dengan menggunakan beberapa teknik analisis yaitu sebagai berikut :

a. Rumus rata-rata (mean) menurut Arikunto (2013),

$\bar{X}=\frac{\sum X}{N}$

$$
\text { Keterangan : } \begin{aligned}
& \overline{\mathrm{X}}=\text { rata-rata skor } \\
& \sum x x=\text { jumlahskor } \\
& \mathrm{N}=\text { jumlah subyek } \\
& \text { penelitian }
\end{aligned}
$$

b. Standar Deviasi menurut Setyosari (2012)

$$
\begin{aligned}
S D=\sqrt{\frac{\sum(\mathrm{X}-\bar{X})^{2}}{N}} \\
\text { Keterangan }: \begin{aligned}
& \frac{\mathrm{SD}}{\mathrm{X}}=\text { Standar Deviasi } \\
& \mathrm{X}=\text { Skor rata-rata } \\
& \text { butir }
\end{aligned} \\
\mathrm{N}=\text { Jumlah subyek }
\end{aligned}
$$

c. Rentang kategori ditentukan dengan menghitung rentang setiap kategori sebagai berikut (Setyosari, 2012) :

Rentang tiap kategori $=\frac{\text { skor maks }- \text { skor min }}{\text { jumlah kategori }}$

Jumlah kategori untuk sikap ilmiah dan hasil belajar kognitif siswa pada penelitian ini ditetapkan empat 
kategori yaitu kurang, cukup, baik, dan sangat baik.

Kemudian data dipersentasikan dengan rumus Arikunto (2013):

Persentase siswa kategori $\mathrm{X}$

$=\frac{\text { Jumlah siswa untuk kategori } \mathrm{X}}{\text { Jumlah seluruh siswa }} \times 100 \%$

d. Pada penelitian ini, digunakan program SPSS versi 22.0 dengan rumus korelasi pearson product moment untuk menganalisis korelasi. Penafsiran didasarkan pada nilai sig pada output dengan ketentuan: sig $\leq$ 0,05 artinya korelasi bersifat signifikan, instrumen valid, atau sig > 0,05 artinya korelasi tidak signifikan, instrumen tidak valid. Untuk memberikan interpretasi terhadap rhitung Product Moment yang diperoleh, digunakan kriteria dari Arifin (2012) sebagai berikut: a) 0,000,20 korelasi sangat lemah; b) 0,210,40 korelasi lemah; c) $0,41-0,60$ korelasi sedang; d) $0,61 \quad-0,80$ korelasi kuat; e) 0,81 - 1,00 korelasi sangat kuat. Dalam korelasi ada dua arah korelasi, yaitu searah dan tidak searah. Pada SPSS hal ini ditandai dengan pesan two tailed. (Westriningsih, 2012).

\section{HASIL DAN PEMBAHASAN}

Berdasarkan hasil analisis data, pada penelitian ini dapat dideskripsikan mengenai sikap ilmiah dan hasil belajar kognitif serta korelasi (hubungan) antara hasil belajar kognitif dan sikap ilmiah siswa dengan menggunakan model PBL.

Rata-rata skor sikap ilmiah siswa kelas VII. 2 SMP Negeri 4 kota Bengkulu pada pembelajaran IPA Biologi dengan materi saling ketergantungan antar komponen biotik, mengunakan model PBL (Problem Based Learning) adalah sebesar 3,26 dengan standar deviasi yaitu 0,25. Berdasarkan rentang kategori untuk sikap ilmiah yang ditetapkan sebelumnya, rata- rata skor yang diperoleh untuk sikap ilmiah pada penelitian ini termasuk dalam kategori sikap ilmiah yang sangat baik karena berada pada kisaran 3,254,00.Presentase kategori sikap ilmiah siswa dapat diihat pada Gambar 1.

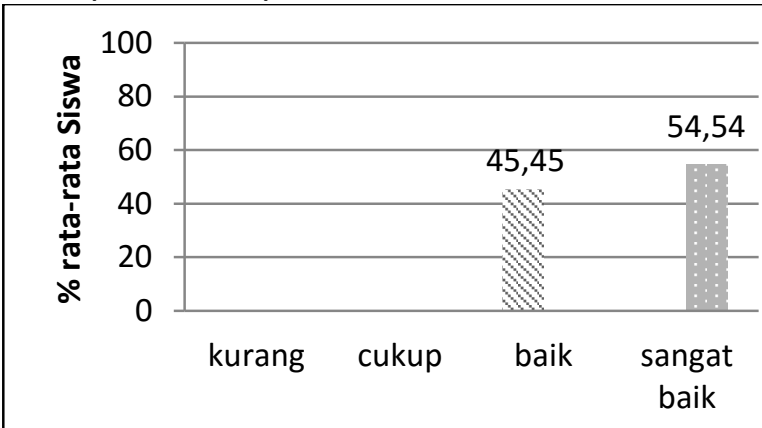

Kategori Sikap IImiah Slswa Pada Pembelajaran IPA Blologi dengan PBL

Gambar 1. Kategori Sikap IImiah

Berdasarkan Gambar 1. dapat dilihat bahwa untuk kategori sikap ilmiah individu siswa, dari 33 siswa diperoleh $45,46 \%$ siswa berkategori baik dan $54,54 \%$ siswa meiliki sikap ilmiah yang berkategori sangat baik. Untuk rata-rata pada masingmasing aspek sikap ilmiah, ditunjukkan pada gambar 2 .

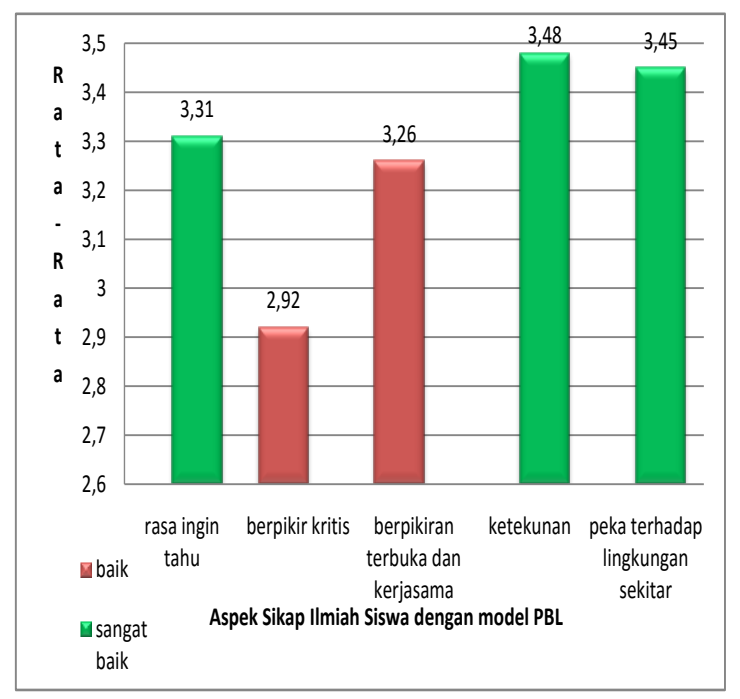

Gambar 2. Rata-rata skor aspek sikap ilmiah

Aspek sikap imiah rasa ingin tahu memeproleh skor rata-rata 3,31 dengan kategori sangat baik. Berdasarkan hasil tersebut, artinya sikap rasa ingin tahu telah ditunjukkan siswa dengan sangat baik pada saat proses pembelajaran berlangsung. 
Sikap rasa ingin tahu menurut Kartono (2012) merupakan sikap dan tindakan yang selalu berupaya untuk mengetahui lebih mendalam dan meluas dari sesuatu yang dipelajarinya, dilihat dan didengar.

Pertama pada saat tahap orientasi siswa pada masalah, siswa sudah mulai menunjukkan rasa ingin tahunya dengan selalu memperhatikan apa yang dijelaskan oleh guru, saat kegiatan eksplorasi ditunjukkan dengan antusias siswa yang mengajukan pertanyaan tentang objek dan peristiwa yang terjadi pada proses rantai makanan. Setelah siswa menerima informasi-informasi baru, maka rasa ingin tahu mereka juga semakin bertambah. Saat kesulitan menjawab pertanyaan, siswa berusaha mencari informasi yang dibutuhkan dengan menggunakan buku siswa. siswa mendapatkan pengetahuan lebih dalam setelah menemukan hal yang menarik dari materi yang didiskusikan tentang rantai makanan.

Aspek berpikir kritis tercermin pada butir sikap ilmiah nomor 4 dan 5 dengan indikator meragukan pendapat teman dan tidak mengabaikan data meskipun kecil. skor rata-rata aspek berpikir kritis yaitu 2,92 dengan kategori baik. sikap berpikir kritis tidak secara mudah dapat ditanamkan dalam diri seluruh siswa. Hal ini terlihat dari indikator 4 pada butir sikap ilmiah nomor 4 yaitu sulit menerima pendapat teman tanpa disertai literatur yang akurat. Butir sikap ilmiah ini memperoleh skor rata-rata yang terendah dari indikator lainnya, meskipun tetap tergolong kategori baik dan indikator lainnya pada aspek berpikir kritis tergolong sangat baik.

Untuk aspek berpikiran terbuka dan kerjasama diukur pada butir 6-10. Skor rata-rata tertinggi berturut-turut pada butir nomor 10, 7 dan 8 yaitu 3.39, 3.30 dan 3.27, ketiganya memiliki kategori sangat baik. Sedangkan 2 butir sikap ilmiah lainnya yaitu pada nomor 6 dan 9 yaitu
3,21 dan 3,15 dengan kategori baik. Selama pembelajaran, siswa menunjukkan aspek sikap ilmiah ini dengan menghargai pendapat dari temannya, meskipun pendapat temannya itu tidak langsung di masukkan kedalam LKS dan tetap dipertimbangkan bersama. Jika pendapat temannya disertai dengan bukti yang mendukung dan akurat dan siswa tersebut merasa pendapat temannya lebih baik, maka siswa tersebut mau mengubah pendapatnya dan bersedia menerima saran dari teman. Hal ini membuktikan bahwa siswa juga memiliki sikap kerjasama yang baik. Terbukti, dalam melakukan kegiatan eksplorasi siswa dengan baik bekerjasama dengan kelompoknya dan dalam berdiskusi pun siswa memiliki peranan dalam kelompoknya.

Pada aspek ketekunan, rata-rata skor pada aspek sikap ilmiah ini memiliki skor tertinggi yaitu 3,48 dengan kategori sangat baik, yang tercermin pada indikator melengkapi satu kegiatan meskipun teman sekelasnya selesai lebih awal, dan dibuktikan dengan butir sikap ilmiah nomor 11. Hal ini terbukti, siswa menyelesaikan semua pertanyaan yang diberikan di LKS. Dan pada aspek peka terhadap lingkungan tercermin pada butir angket nomor 12 pada indikator menjaga kebersihan lingkungan sekolah. Saat melaksanakan kegiatan eksplorasi siswa tidak mengabaikan peringatan dari guru yang meminta untuk tidak memetik tanaman dan tidak mengotori halaman sekolah sebagai tempat eksplorasi. Hal ini dibuktikan dengan skor rata-rata aspek sikap ilmiah ini berkategori sangat baik, yaitu 3,45.

Berdasarkan data hasil penelitian, persentase kategori hasil belajar kognitif siswa sebesar $72,72 \%$ dari total 33 siswa yang tergolong kategori hasil belajar kognitif baik, sementara $27,27 \%$ tergolong kategori sangat baik. Presentase tersebut dapat dilihat pada Gambar 3. 


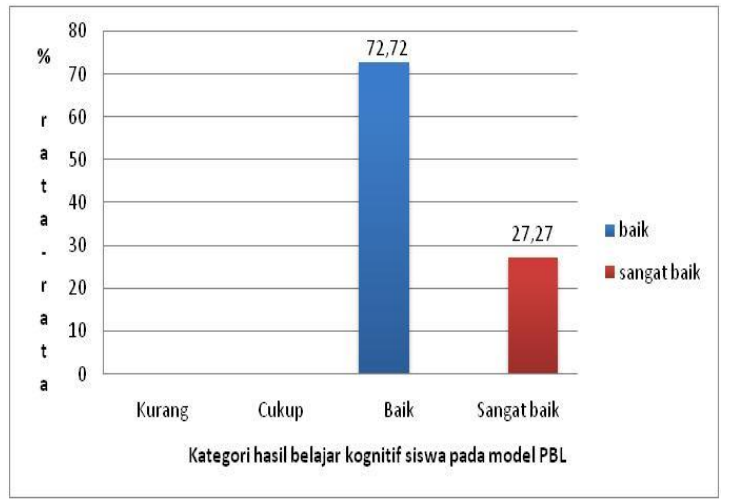

Gambar 3. Persentase kategori hasil belajar kognitif siswa

Tes hasil belajar kognitif siswa pada pembelajaran IPA Biologi dengan model PBL ini terdiri dari 4 soal tes esai dan 1 soal dibagi menjadi 2 yaitu bagian $a$ dan $b$, sehingga total soal tes ini ada 5. Pada soal nomor 1, dari 33 siswa terdapat 17 siswa yang dapat menjawab soal dengan benar dan tepat, 15 menjawab dengan benar namun kurang tepat. Hal ini menunjukkan bahwa siswa telah memahami konsep rantai makanan yang telah dipelajari. Pada butir soal 4a 28 siswa menjawab dengan benar dan tepat, sedangkan 5 siswa menjawab dengan benar namun kurang tepat. Butir soal ini merupakan soal yang paling banyak dijawab benar oleh siswa. Butir soal $4 \mathrm{~b}$ dijawab dengan benar dan tepat oleh 24 siswa dan 9 orang siswa menjawab benar namun kurang tepat.

Indikator kedua tercermin pada soal nomor 2 dan 3. Pada soal nomor 2 hanya 9 siswa yang menjawab dengan benar dan tepat yaitu menjelaskan proses peristiwa rantai makanan sesuai dengan gambar yang diberikan pada soal dan 24 siswa menjawab dengan benar namun kurang tepat.

Analisis korelasi antara sikap ilmiah dan hasil belajar kognitif menggunakan SPSS versi 22.0 for windows diperoleh nilai signifikan 0,005. Berarti nilai signifikansi $\leq$ 0,05 sehingga $\mathrm{HO}$ ditolak dan Ha diterima, yang artinya ada korelasi antara sikap ilmiah dan hasil belajar kognitif siswa kelas $\mathrm{VII}_{2}$ SMP Negeri 4 kota Bengkulu pada pembelajaran IPA dengan model problem based learning. Nilai koefisien korelasi yaitu +0,482, sehingga korelasi antara sikap ilmiah dan hasil belajar kognitif merupakan korelasi searah atau berbanding lurus (positif).

Berdasarkan kriteria Arifin (2012) bahwa interprestasi terhadap koefesien korelasi yang diperoleh antara sikap ilmiah dan hasil belajar kognitif siswa termasuk korelasi yang sedang yaitu berada diantara $0,41-0,60$. Artinya, hubungan antara sikap ilmiah dan hasil belajar kognitif siswa kelas $\mathrm{VII}_{2}$ SMP $\mathrm{N} 4$ kota Bengkulu tergolong sedang. Berikut merupakan gambar yang menunjukkan korelasi antara sikap ilmiah siswa dan hasil belajar kognitif siswa. Untuk melihat korelasi atau hubungan antara hasil belajar kognitif dan sikap ilmiah siswa pada pembelajaran IPA Biologi dengan model PBL dapat dillihat pada Gambar 4. 


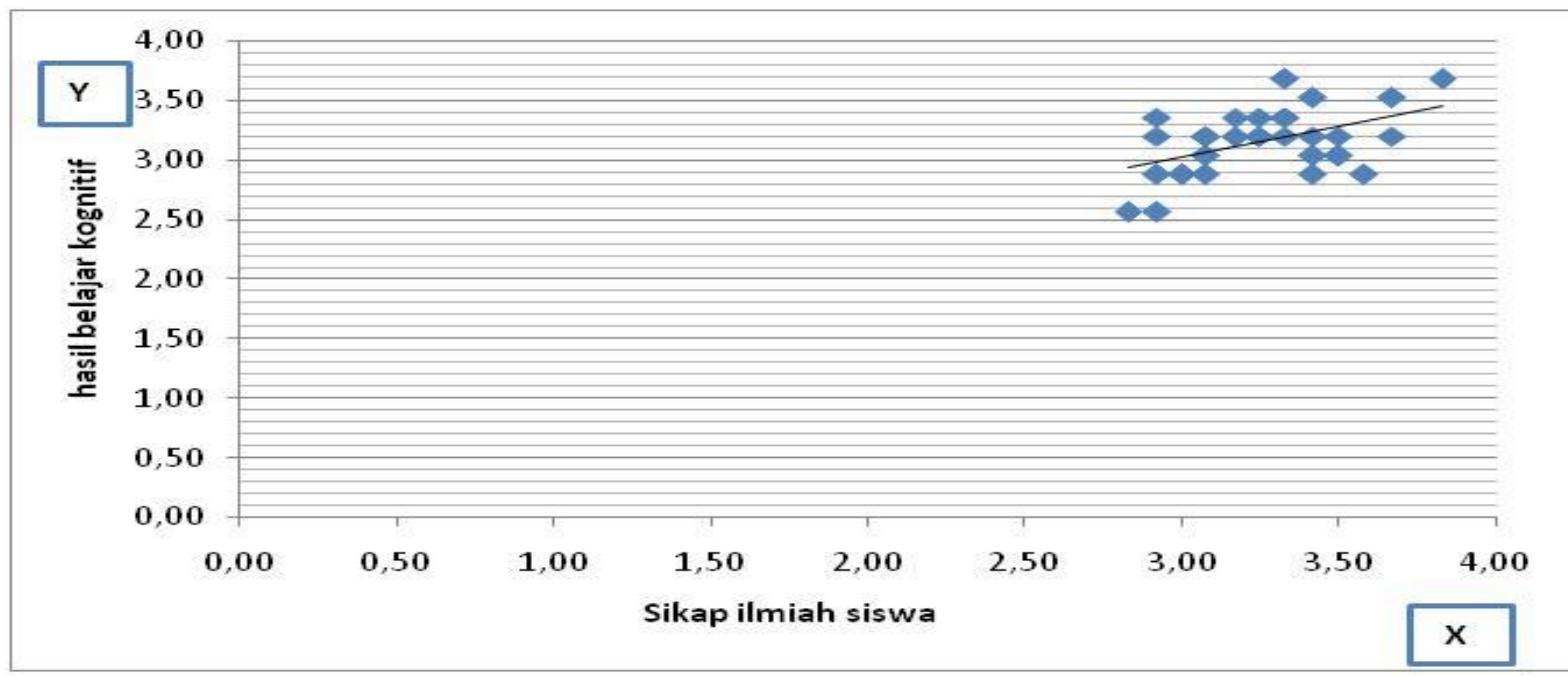

Gambar 4. Korelasi antara hasil belajar kognitif dan sikap ilmiah siswa pada pembelajaran IPA Biologi dengan model PBL

Pada Gambar 4.5 sumbu horizontal (X) merupakan skor sikap ilmiah siswa dan sumbu vertikal (Y) merupakan nilai hasil belajar kognitif siswa. Berdasarkan pencaran titik tersebut, terdapat garis lurus yang condong ke arah kanan, menunjukkan bahwa korelasi antara sikap ilmiah dan hasil belajar kognitif siswa merupakan korelasi positif atau berjalan searah. Artinya, sikap ilmiah siswa akan meningkat apabila hasil belajar kognitif siswa meningkat dan sebaliknya. Namun, plot warna biru yang cenderung membentuk garis lurus yang agak sempit namun tersebar menunjukkan hubungan antara sikap ilmiah dan hasil belajar kognitif tergolong korelasi sedang. Artinya, peningkatan kedua variabel tidak selalu memiliki hasil yang sama meskipun kedunya merupakan korelasi yang signifikan.

\section{PENUTUP}

\section{Simpulan}

Berdasarkan penelitian yang telah dilakukan, dapat disimpulkan bahwa sikap ilmiah siswa kelas $\mathrm{VII}_{2}$ SMP $\mathrm{N} 4$ kota Bengkulu pada pembeljaran IPA Biologi dengan model problem based learning dengan kategori sangat baik dan Hasil belajar kognitif siswa kelas $\mathrm{VII}_{2}$ SMP Negeri 4 kota Bengkulu pada pembelajaran IPA
Biologi dengan model problem based learning berkategori baik serta ada korelasi yang positif antara sikap ilmiah dan hasil belajar kognitif siswa,korelasi ini tergolong korelasi sedang.

\section{Saran}

Berdasarkan penelitian yang telah dilakukan, maka dapat disarankan :

1. Bagi pendidik, adanya korelasi antara sikap ilmiah dan hasil belajar kognitif pada penelirtian ini, maka diharapkan pada proses pembelajaran dapat mengembangkan sikap ilmiah siswa melalui proses pembelajran yang melibatkan siswa secara aktif dalam proses pembelajaran salah satunya dengan menerapkan model problem based learning

2. Bagi peneliti lanjutan agar dapat melakukan penelitian lebih lanjut yang serupa dengan penelitian ini. Ataupun bisa diperluas lagi dengan menambah aspek sikap ilmiah yang akan diuji. Agar kevalidan data semakin meningkat, maka diharapkan dapat menggunakan lembar observasi sikap ilmiah. 


\section{DAFTAR PUSTAKA}

Arifin, Z. 2012. Evaluasi Pembelajaran. Bandung : PT Remaja Rosdakarya

Arikunto, S. 2013. Dasar-Dasar Evaluasi Pendidikan. Jakarta: Bumi Aksara

Astuti, E. J. 2014. Analisis Korelasi Antara Sikap Ilmiah Dan Prestasi Belajar Siswa Kelas Viii5 Smpn 4 Bengkulu Pada Pembelajaran IPA Biologi Dengan Model Siklus Belajar 5E

Kartono. 2012. Pengembangan Model Penilaian Sikap IImiah IPA bagi Mahasiswa PGSD. Jurnal FKIP UNS

Peraturan Menteri Pendidikan dan Kebudayaan Republik Indonesia Nomor 58 tahun 2014
Putra, S. R. 2013. Desain Belajar Mengajar Kreatif Berbasis Sains. Yogyakarta: Diva Press

Setyosari, P. 2012. Metode Penelitian Pendidikan dan Pengembangan. Jakrta: Kencana

Sutirman. 2013. Media dan Model-Model Pembelajaran Inovatif. Yogyakarta: Graha Ilmu

Westriningsih. 2012. Solusi Praktis dan Mudah Menguasai SPSS 20 untuk Pengolahan Data. Semarang: Wahana Komputer

Widyoko, S. E. P. 2012. Evaluasi Program Pembelajaran. Yogyakarta: Pustaka Belajar 